\title{
WestVirginiaUniversity.
}

Department of Economics

Working Paper Series

\section{Institutional Convergence: Exit or Voice?}

Joshua C. Hall

Working Paper No. 15-40

This paper can be found at the College of Business and Economics

Working Paper Series homepage: 


\title{
Institutional Convergence: Exit or Voice?
}

\author{
Joshua C. Hall* \\ West Virginia University
}

September 2015

\begin{abstract}
There is a small but growing literature on the determinants of economic freedom. In this paper I contribute to this literature in two ways. First, I empirically show that $\beta$-convergence in economic freedom occurred from 1980 to 2010. Countries with low levels of economic freedom in 1980 "catch up" at a rate of 0.7 percent a year on average, ceteris paribus. Second, I document the structural characteristics that contribute to this institutional convergence. My conditional convergence estimates suggest democratic institutions do not contribute to conditional convergence. Exitability, a variable that captures how easy it is for citizens to "vote with their feet" is related to the change in economic freedom from 1980 to 2010 in a statistically significant manner across all specifications. This provides some to the importance of "exit" versus "voice" with respect to the question of institutional change.
\end{abstract}

JEL Codes: O1, O43, P1, P48

Key Words: Convergence, Economic Freedom, Institutional Change, Democracy, Exit

${ }^{*}$ Department of Economics, College of Business and Economics, PO Box 6025, Morgantown WV 26506-6025; email: joshua.hall@mail.wvu.edu.

Acknowledgments: Hall would like to thank the John Templeton Foundation and the Free Market Institute at Texas Tech University for financial support. Matthew Brown also generously shared his data on exitability. Comments from Russell Sobel, Andrew Young, and Benjamin Powell were very helpful in revising the paper. 


\section{Introduction}

While the study of the institutions of economic freedom has a long history in economics going back at least to Adam Smith, the creation of the Economic Freedom of the World (EFW) index by Gwartney et al. (1996) has led a large number of economists to study the effect of economic freedom on social, political, and economic outcomes. ${ }^{1}$ Hall and Lawson (2014) provide an accounting of a subset of the literature using the EFW index. Focusing only on journals listed in the Social Science Citation Index, they find 402 articles citing the EFW index since 1996. Of those 402 articles, 198 are empirical papers using the EFW index as an explanatory variable. After reading and categorizing all the articles, Hall and Lawson (2014) find that fewer than $4 \%$ of the articles surveyed found economic freedom to be associated with a normatively "bad" outcome such as income inequality or obesity. ${ }^{2}$

The modal paper in the literature using the EFW index focuses on the relationship between economic freedom and growth. This literature almost uniformly shows that an institutional environment more consistent with economic freedom is conducive to long-term growth. An early paper by Gwartney et al. (1999) finds that a one unit change in the EFW index during the 1975-1985 period was associated with an 0.8 percentage point increase in a country's long term growth rate. Looking at the 1990s and controlling for the effect that economic freedom has on the productivity of investment, Gwartney et al. (2006) find that a one unit change in the EFW index is associated with a 1.5 percentage point increase in growth. A critical survey of the literature by De Haan et al. (2006) finds strong evidence that increases in the EFW index stimulates growth. A 2011 meta-regression analysis by Efendic et al. (2011) finds similar results,

\footnotetext{
${ }^{1}$ Gwartney and Lawson (2003) provides a good overview of the theoretical foundations behind the construction of the EFW index.

${ }^{2}$ Apergis et al. (2014) actually finds bi-directional causality between income inequality and economic freedom.
} 
albeit with some suggestions for improvement within for scholars working in the area. Other important recent works include Williamson and Mathers (2011), Rode and Coll (2012), and Young and Sheehan (2014).

If the institutions of economic freedom are associated with economic growth, then the next logical question is what causes countries to turn towards or away from market oriented institutions? What exactly are the determinants of economic freedom? While many have been discussed in the literature, a prominent determinant in the literature has been political freedom, or democratic institutions. An early paper in this literature is Dawson (1998), who finds that the level of economic freedom in 1990 is related to political freedom in 1975. Wu and Davis (1999), however, finds no effect of political freedom on economic freedom. More recent work by De Haan and Sturm (2003), Pitlik and Wirth (2003), Lundström (2005), and Rode and Coll (2012) find that political freedom or democratic transitions lead to economic freedom. This finding is supported by papers by Dawson (2003), Vega-Gordillo and Alvarez-Arce (2003), and Aixalá and Fabro (2009) who present evidence that political freedom granger-causes economic freedom. Sobel and Coyne (2011) find that political and economic institutions are cointegrated and therefore move together through time within a country. ${ }^{3}$ The case for political freedom has also been backed by within-country case studies, such as the work of Beaulier and Subrick (2006) on Botswana.

Other long-run determinants of the institutions of economic freedom include the historical origins of a country's laws (La Porta et al., 1999, 2008). Legal origin theory is based on the idea that the British common law created more effective constraints on the power of the executive than did French civil law or Scandinavian or Socialist legal origins (Du, 2010). ${ }^{4}$ Similarly, countries that are fractionalized in terms of ethnicity,

\footnotetext{
${ }^{3}$ Lawson and Clark (2010) find very few cases of countries with high levels of political freedom and economic freedom.

${ }^{4}$ Nattinger and Hall (2012) find that the legal origins of U.S. states help explain their current levels
} 
religion, or language might have lower levels of economic freedom as it is harder for diverse individuals to agree on publicly-provided goods (Alesina et al., 2003). In a paper looking at the long-run determinants of growth, Easterly et al. (2006) find that ethnolinguistic fractionalization affects institutional quality, which in turn influences growth.

An important addition to this literature is the work of Brown (2014). Building off of the work of Diamond (1997) who briefly notes that the shape of Europe versus China could have influenced their institutional development. Europe, unlike China, is geographically indented and has more peninsulas and islands, which created natural barriers to population centralization and control. Brown (2014) links this literature to institutional competition, which requires the ability of citizens to "vote with their feet" (Tiebout, 1956). The closer and individual is in a country to a border, the closer they are to an alternative institutional environment. Brown (2014) creates a variable called "exitability" to capture this concept. ${ }^{5}$ Defined as the sum of land borders and coastline divided by total geographic area, his measure of the 'exitability' of a country is a long-run determinant of economic freedom in his empirical work. ${ }^{6}$

In this paper I add to this literature on the determinants of economic freedom by seeing how specific determinants contributed to institutional convergence from 1980 to 2010. This is an important question for four reasons. First, the question of income convergence across countries has interested economists since the seminal papers by of economic freedom.

${ }^{5}$ In many ways, this variable and they thesis behind it is related to the work of Scott (2009). For more on the relationship between Scott (2009) and competition in governance, see Powell and Nair (2012) and Stringham and Miles (2012).

${ }^{6}$ In addition to this literature on the deep determinants, there are a number of papers on how economic freedom responds to more short-run changes, such as in preferences (Crampton, 2002), foreign aid (Powell and Ryan, 2006; Young and Sheehan, 2014), immigration (Clark et al., 2014), ideas (Leeson et al., 2012), changes in nearby countries (Leeson et al., 2012), internet access (Sheehan and Young, 2014), and joining a monetary and fiscal union (Hall et al., 2011). While important, these are outside the scope of this paper, which focuses on initial conditions and time-invariant determinants such as exitability. 
Barro and Sala-i-Martin (1992) and Sala-i-Martin (1996). Second, Knack and Keefer (1995), Knack (1996), and Keefer and Knack (1997) show that convergence depends on the quality of institutions. By better understanding the process of convergence in economic freedom across countries, scholars can better understand the causes of continued income differences across countries. Third, while many studies have documented how various determinants such as political freedom have influenced economic freedom, no studies have quantified how these determinants contribute to the speed at which countries with poor institutional quality catch up to those with good institutional quality. Finally, my paper contributes to the literature on exit versus voice in determining the quality of institutions (Hirschman, 1978).

My paper proceeds as follows. In Section 2, I describe my data and empirical approach. Section 3 presents the empirical results and Section 4 concludes.

\section{Empirical Approach and Data}

In the growth literature there is a large body of work on the convergence of incomes across countries or regions (Barro and Sala-i-Martin, 1992; Mankiw et al., 1992). A large portion of this literature focuses on $\beta$-convergence. $\beta$-convergence is when the partial correlation between growth in income over some time period is negatively related to the initial level of income (Young et al., 2008). While there is a large body of literature on $\beta$-convergence in incomes, there is almost zero literature on $\beta$-convergence in economic freedom or institutions. A search for papers on institutional convergence yielded three working papers. The first paper, by Savoia and Sen (2012), looks for

$\beta$-convergence across a number of different institutional measures, including Area 2 of the EFW report. In addition to not using the entire EFW index, the focus of their paper is just testing for convergence since they do not report coefficients for their 
conditional convergence regressions and employ largely time-invariant data using a panel approach. The second paper by Elert and Halvarsson (2012) does use the entire EFW index as its measure of institutions and finds evidence for convergence using a panel data approach. However, they do not control for any other determinants of the change in economic freedom other than the initial value of economic freedom and the change in economic freedom over the time period. ${ }^{7}$ Finally, a very recent paper by Boudreaux and Holcombe (2015) looks at institutional convergence for an unbalanced panel of countries from 1970 to 2010.

My measure of economic freedom is the Economic Freedom of the World (EFW) index by Gwartney et al. (2015). A widely used political economy indicator, the EFW measures the economic freedom present in a country based on 42 variables in five areas: size of government, legal system and property rights, sound money, freedom to trade internationally, and the regulation of business, credit, and labor. Each component is placed onto 0-10 scale and then aggregated to create a summary measure of economic freedom for the country as a whole. The index contains 157 countries in the most recent year (2013) and a smaller number of countries going back to $1970{ }^{8}$ I choose 1980 as my initial year instead of 1970 as the number of countries rated in 1980 is considerably higher than in 1970, especially for the chain-linked version of the index, which tries to adjust for changes in the components of the index over time. I only employ the chain-link measure of economic freedom in my analysis.

I test for convergence in institutional quality using the following equation:

$$
\ln E F W_{2010}-\ln E F W_{1980}=\alpha+\beta E F W_{1980}+\gamma X_{1980}+\epsilon
$$

where $X_{1980}$ is a matrix of variables that might explain long-run determinants of

\footnotetext{
${ }^{7}$ Another similar recent paper is Heckelman (2015), who tests for $\sigma$-convergence in economic freedom.

${ }^{8}$ The data is annual back to 2000 and at five-year intervals from 1970 to 2000.
} 
the change in the natural log of economic freedom from 1980 to 2010. A negative sign on the parameter $\beta$ implies that there is convergence in economic freedom. Conversely, a positive sign on $\beta$ would imply divergence in economic freedom from 1980 to 2010 among this sample of countries. My choice of variables to include in the $X$ matrix are motivated by the literature on the determinants of economic freedom discussed in the introduction. GDP per capita in 1980 in constant 2005 U.S. dollars was obtained from World Bank (2015). To capture the the quality of human capital in 1980, I include the average years of secondary schooling for the total population 25 and older in 1980 from Barro and Lee (2013). Descriptive statistics for all non-binary data used in the paper is presented in Table 1.

To see how the initial level of political institutions contributed to the change in economic freedom from 1980 to 2010, I include the level of political democracy in 1980 from Marshall et al. (2014). Widely used as a measure of democracy in a number of studies (Glaeser et al., 2004; Leeson and Dean, 2009), the measure ranges from 10 ("total autocracy") to +10 ("total democracy"). This variable captures political openness, the competitiveness of the political process, and constraints on the chief executive (Leeson and Dean, 2009). As an additional political institution variable I also include Checks from Beck et al. (2001). As created by Keefer and Stasavage (2003), Checks is trying to capture the number of veto players in government. This variable is based on whether the executive and legislature are controlled by different parties in a presidential system) or the number of parties in the government coalition (in parliamentary systems). The measure is also adjusted for political rules that make coalitions more cohesive. Countries with a higher score on Checks are expected to have higher economic freedom as the scope for collective activity is limited.

To test whether the threat of exit plays an important role in explaining convergence in economic freedom over this period I include Exitability from Brown (2014). As 
Table 1: Summary Statistics

\begin{tabular}{lrrrrr}
\hline Name & Observations & Mean & St. Dev. & Min & Max \\
\hline EFW Growth & 102 & 0.01 & 0.01 & -0.02 & 0.03 \\
1980 EFW & 102 & 5.31 & 1.26 & 2.76 & 9.03 \\
1980 GDP (ln) & 100 & 7.97 & 1.06 & 5.78 & 10.60 \\
1980 Education & 98 & 1.29 & 1.08 & 0.05 & 5.10 \\
Democracy & 90 & 0.21 & 8.08 & -10.00 & 10.00 \\
Checks and Balances & 100 & 3.13 & 1.14 & 1.00 & 5.73 \\
Exitability & 100 & 0.050 & 0.103 & 0.003 & 0.699 \\
Ethnic Fractionalization & 102 & 0.438 & 0.268 & 0.002 & 0.930 \\
Language Fractionalization & 100 & 0.391 & 0.297 & 0.002 & 0.923 \\
Religious Fractionalization & 102 & 0.430 & 0.240 & 0.003 & 0.860 \\
\hline
\end{tabular}

discussed in the introduction, this variable is defined as the "sum of land borders and coastline divided by total geographic area" (Brown, 2014, p. 110). A country's Exitability score is higher when the length of its border and coastline to its total area is greater. So countries with irregular borders, like Denmark and Panama have relatively high scores (0.17 and 0.039 respectively). A country like Chad with a large land mass and smooth borders has a low score of 0.004 .

Between exitability and democracy, we have the ability to test how these structural characteristics contribute to conditional convergence in economic freedom from 1980-2010. Do countries that were similar in terms of democracy in 1980 converge faster than countries that were similar in terms of exit? The coefficient estimates on Democracy and Exitability should be able to shed some light on this question. The final variables included in my regressions to explain $\beta$-convergence in economic freedom across countries are variables representing legal origins (La Porta et al., 1999, 2008) and ethnic, religious, and linguistic fractionalization (Alesina et al., 2003). 


\section{Empirical Results}

Column (1) of Table 2 presents the unconditional convergence estimates over the 1980 to 2010 period for the EFW index. The negative and statistically significant coefficient on 1980 EFW demonstrates that economic freedom has been converging since 1980. To put these estimates in context, consider that Argentina had a score in the EFW index in 1980 of 3.96. According to the unconditional convergence estimates in column (1), the expected annual growth in economic freedom will be $0.0329-0.00450 \times 3.96=0.015$ percentage points. This implies that over the 30 -year period, economic freedom in Argentina would reach an EFW score of $3.96 \times e^{30 \times 0.015}=6.21$ if it were converging at the average rate. In reality, Argentina had an EFW score of 5.86 in 2010.

Table 2: Convergence in Economic Freedom: Baseline Results

\begin{tabular}{lccc}
\hline & $(1)$ & $(2)$ & $(3)$ \\
\hline 1980 EFW & $-0.00450^{* * *}$ & $-0.00532^{* * *}$ & $-0.00559^{* * *}$ \\
& $(0.000408)$ & $(0.000498)$ & $(0.000518)$ \\
1980 GDP (ln) & & $0.00143^{* *}$ & 0.000589 \\
& & $(0.000448)$ & $(0.000510)$ \\
1980 Education & & & $0.00157^{* * *}$ \\
& & & $(0.000380)$ \\
Constant & $0.0329^{* * *}$ & $0.0260^{* * *}$ & $0.0321^{* * *}$ \\
& $(0.00227)$ & $(0.00311)$ & $(0.00407)$ \\
\hline$N$ & 102 & 100 & 96 \\
adj. $R^{2}$ & 0.593 & 0.651 & 0.663
\end{tabular}

Dependent variable is the change in the natural log of the EFW index from 1980-2010.

Robust standard errors in parentheses.

${ }^{*} p<0.05,{ }^{* *} p<0.01,{ }^{* * *} p<0.001$

Convergence not only means that countries that begin the period with low levels of economic freedom "catch up," but also that some countries that begin the period 
with a high level of economic freedom might stagnate institutionally or decline. Once you have eliminated conscription, for example, there is no way to get freer on that component of the EFW. Consider the United States, which began 1980 with an EFW score of 7.92. Again using the estimates from column (1) the expected annualized growth rate in economic freedom for the United States will be $0.0329-0.00450 \times 7.92=$ -0.0027 percentage points. After 30 years, this would predict that an EFW score of $7.92 \times e^{30 \times-0.0027}=7.29$. In reality, the United States had a chain-link EFW score of 7.76 in 2010.

Clearly, it is necessary to look at institutional convergence conditional on other factors such as initial GDP levels and human capital levels. Columns (2) and (3) from Table 2 introduce both of these variables. The natural log of 1980 GDP per capita is positively related to the speed of economic freedom convergence in Column (2) but its statistical significance disappears once 1980 Education is introduced in Column (3), with years of secondary education of those over 25 (in 1980) being statistically significant at the one percent level. The coefficient on 1980 EFW in Column (3) suggests that a country with a low initial EFW will close the institutional gap with countries at the top of the economic freedom rankings like Hong Kong and Singapore at a rate of 0.5 percent annually, other things being equal.

What about Democracy and Exitability? Table 3 introduces Democracy, Checks, and Exitability one at a time. Democracy as measured by the Polity IV data is not statistically significant in any of the specifications. The same is also true for Checks. Exitability, however, is positively related to institutional convergence in Column (3) of Table 3. This implies that countries with more uneven borders or longer borders relative to their total area converged more than other countries conditional on initial levels of economic freedom. Other important things to note are that 1980 Education retains its significance with the inclusion of these additional variables. Once more 
Table 3: Convergence in Economic Freedom: Politics and Exit

\begin{tabular}{lccc}
\hline & $(1)$ & $(2)$ & $(3)$ \\
\hline 1980 EFW & $-0.00590^{* * *}$ & $-0.00591^{* * *}$ & $-0.00630^{* * *}$ \\
& $(0.000533)$ & $(0.000529)$ & $(0.000508)$ \\
1980 GDP $(\ln )$ & 0.000637 & 0.000637 & 0.0000453 \\
& $(0.000702)$ & $(0.000706)$ & $(0.000720)$ \\
1980 Education & $0.00166^{* *}$ & $0.00173^{* * *}$ & $0.00209^{* * *}$ \\
& $(0.000494)$ & $(0.000476)$ & $(0.000505)$ \\
Democracy & 0.0000185 & 0.0000300 & 0.0000247 \\
& $(0.0000865)$ & $(0.000102)$ & $(0.0000993)$ \\
Checks & & -0.000208 & 0.00000958 \\
& & $(0.000515)$ & $(0.000538)$ \\
Exitability & & & $0.0303^{* *}$ \\
& & & $(0.0108)$ \\
Constant & $0.0331^{* * *}$ & $0.0337^{* * *}$ & $0.0382^{* * *}$ \\
\hline$N$ & $(0.00577)$ & $(0.00610)$ & $(0.00607)$ \\
adj. $R^{2}$ & 85 & 84 & 83 \\
\hline & 0.654 & 0.650 & 0.678 \\
\hline
\end{tabular}

Dependent variable is the change in the natural log of the EFW index from 1980-2010.

Robust standard errors in parentheses.

${ }^{*} p<0.05,{ }^{* *} p<0.01,{ }^{* * *} p<0.001$ 
similar countries are taken into account in these conditional convergence specifications, it is not surprising that the estimated $\beta$ becomes larger since institutional convergence should be faster for countries that are similar in important structural ways, like having the same degree of Exitability.

In Table 4 we test the robustness of the findings of Table 3 by including measures of ethnic, language, and religious fractionalization. None of these variables contribute to the convergence of economic freedom over the 1980 to 2010 period in a statistically significant manner. Most importantly, however, Exitability retains its statistical significance across all three columns, as does 1980 Education. The estimate of $\beta$ in column (3) of Table 4 is -0.00648 , suggesting that a country with a low EFW score in 1980 will erode the economic freedom gap at a rate of 0.648 percent a year.

Countries fundamentally change their legal systems infrequently, usually as the result of colonization or initial settlement. Table 5 introduces legal origins. Column (1) introduces a dummy variable equal to one if the country follows the British common law tradition. While the sign on this variable is positive, as expected, it is not statistically significant. Similarly, when the French legal origin binary variable is introduced in column (2), the sign is negative as expected but statistically insignificant as well. Socialist legal origins are introduced in column (3). The variable not only is statistically insignificant, it has the wrong sign (i.e., is positively related to the change in the natural $\log$ of economic freedom from 1980 to 2010.

In terms of our primary variables of interest, Democracy and Exitability, both retain the same conclusion once legal origins are introduced. While the sign on Democracy is now negative, it is statistically indistinguishable from zero. Exitability, on the other hand remains statistically significant even with the inclusion of a large number of covariates and the number of countries falling to 81 . The same is also true of 1980 Education, which also retains its positive and significant relationship with the change 
Table 4: Convergence in Economic Freedom: Including Fractionalization

\begin{tabular}{|c|c|c|c|}
\hline & (1) & $(2)$ & (3) \\
\hline $1980 \mathrm{EFW}$ & $\begin{array}{c}-0.00632^{* * *} \\
(0.000510)\end{array}$ & $\begin{array}{c}-0.00651^{* * *} \\
(0.000675)\end{array}$ & $\begin{array}{c}-0.00648^{* * *} \\
(0.000640)\end{array}$ \\
\hline 1980 GDP (ln) & $\begin{array}{c}0.0000996 \\
(0.000717)\end{array}$ & $\begin{array}{c}0.000509 \\
(0.000883)\end{array}$ & $\begin{array}{c}0.000582 \\
(0.000879)\end{array}$ \\
\hline 1980 Education & $\begin{array}{l}0.00212^{* * *} \\
(0.000527)\end{array}$ & $\begin{array}{l}0.00202^{* * *} \\
(0.000524)\end{array}$ & $\begin{array}{c}0.00182^{* *} \\
(0.000554)\end{array}$ \\
\hline Democracy & $\begin{array}{c}0.0000242 \\
(0.0000996)\end{array}$ & $\begin{array}{c}0.0000332 \\
(0.0000963)\end{array}$ & $\begin{array}{c}0.0000252 \\
(0.0000961)\end{array}$ \\
\hline Checks & $\begin{array}{l}0.0000185 \\
(0.000532)\end{array}$ & $\begin{array}{c}-0.0000258 \\
(0.000495)\end{array}$ & $\begin{array}{l}0.0000355 \\
(0.000517)\end{array}$ \\
\hline Exitability & $\begin{array}{l}0.0307^{* *} \\
(0.0108)\end{array}$ & $\begin{array}{l}0.0290^{* *} \\
(0.0102)\end{array}$ & $\begin{array}{c}0.0279^{* *} \\
(0.00924)\end{array}$ \\
\hline Ethnic Fractionalization & $\begin{array}{l}0.000583 \\
(0.00174)\end{array}$ & $\begin{array}{c}-0.000617 \\
(0.00290)\end{array}$ & $\begin{array}{l}-0.00107 \\
(0.00307)\end{array}$ \\
\hline Language Fractionalization & & $\begin{array}{c}0.00204 \\
(0.00308)\end{array}$ & $\begin{array}{c}0.00144 \\
(0.00281)\end{array}$ \\
\hline Religious Fractionalization & & & $\begin{array}{c}0.00262 \\
(0.00221)\end{array}$ \\
\hline Constant & $\begin{array}{l}0.0375^{* * *} \\
(0.00600)\end{array}$ & $\begin{array}{l}0.0353^{* * *} \\
(0.00632) \\
\end{array}$ & $\begin{array}{l}0.0340^{* * *} \\
(0.00641) \\
\end{array}$ \\
\hline $\begin{array}{l}N \\
\text { adj. } R^{2}\end{array}$ & $\begin{array}{c}83 \\
0.674\end{array}$ & $\begin{array}{c}82 \\
0.668\end{array}$ & $\begin{array}{c}82 \\
0.671\end{array}$ \\
\hline
\end{tabular}

Dependent variable is the change in the natural log of the EFW index from 1980-2010. Robust tandard errors in parentheses.

${ }^{*} p<0.05,{ }^{* *} p<0.01,{ }^{* * *} p<0.001$ 
Table 5: Convergence in Economic Freedom: Including Legal Origins

\begin{tabular}{|c|c|c|c|}
\hline & (1) & (2) & (3) \\
\hline $1980 \mathrm{EFW}$ & $\begin{array}{c}-0.00645^{* * *} \\
(0.000691)\end{array}$ & $\begin{array}{c}-0.00645^{* * *} \\
(0.000687)\end{array}$ & $\begin{array}{c}-0.00642^{* * *} \\
(0.000710)\end{array}$ \\
\hline 1980 GDP (ln) & $\begin{array}{c}0.000860 \\
(0.000901)\end{array}$ & $\begin{array}{c}0.00100 \\
(0.000921)\end{array}$ & $\begin{array}{c}0.000996 \\
(0.000910)\end{array}$ \\
\hline 1980 Education & $\begin{array}{c}0.00176^{* *} \\
(0.000591)\end{array}$ & $\begin{array}{c}0.00159^{* *} \\
(0.000577)\end{array}$ & $\begin{array}{c}0.00164^{* *} \\
(0.000585)\end{array}$ \\
\hline Democracy & $\begin{array}{r}-0.00000803 \\
(0.0000990)\end{array}$ & $\begin{array}{c}-0.0000108 \\
(0.0000992)\end{array}$ & $\begin{array}{c}-0.00000551 \\
(0.000101)\end{array}$ \\
\hline Checks & $\begin{array}{l}0.0000444 \\
(0.000516)\end{array}$ & $\begin{array}{l}0.0000479 \\
(0.000513)\end{array}$ & $\begin{array}{l}0.0000614 \\
(0.000514)\end{array}$ \\
\hline Exitability & $\begin{array}{c}0.0247^{* *} \\
(0.00931)\end{array}$ & $\begin{array}{c}0.0237^{*} \\
(0.00955)\end{array}$ & $\begin{array}{c}0.0241^{*} \\
(0.00949)\end{array}$ \\
\hline Ethnic Fractionalization & $\begin{array}{c}-0.00130 \\
(0.00308)\end{array}$ & $\begin{array}{c}-0.000665 \\
(0.00309)\end{array}$ & $\begin{array}{c}-0.000558 \\
(0.00316)\end{array}$ \\
\hline Language Fractionalization & $\begin{array}{c}0.00111 \\
(0.00281)\end{array}$ & $\begin{array}{c}0.00121 \\
(0.00284)\end{array}$ & $\begin{array}{c}0.00136 \\
(0.00282)\end{array}$ \\
\hline Religious Fractionalization & $\begin{array}{c}0.00139 \\
(0.00222)\end{array}$ & $\begin{array}{l}0.000928 \\
(0.00226)\end{array}$ & $\begin{array}{l}0.000676 \\
(0.00237)\end{array}$ \\
\hline UK Legal Origins & $\begin{array}{c}0.00167 \\
(0.000986)\end{array}$ & $\begin{array}{l}0.000522 \\
(0.00115)\end{array}$ & $\begin{array}{l}0.000978 \\
(0.00117)\end{array}$ \\
\hline French Legal Origins & & $\begin{array}{c}-0.00150 \\
(0.00110)\end{array}$ & $\begin{array}{c}-0.00103 \\
(0.00119)\end{array}$ \\
\hline Socialist Legal Origins & & & $\begin{array}{c}0.00209 \\
(0.00183)\end{array}$ \\
\hline Constant & $\begin{array}{l}0.0320^{* * *} \\
(0.00630)\end{array}$ & $\begin{array}{l}0.0322^{* * *} \\
(0.00616)\end{array}$ & $\begin{array}{l}0.0315^{* * *} \\
(0.00619)\end{array}$ \\
\hline $\begin{array}{l}N \\
\text { adj. } R^{2}\end{array}$ & $\begin{array}{c}81 \\
0.658\end{array}$ & $\begin{array}{c}81 \\
0.657\end{array}$ & $\begin{array}{c}81 \\
0.653\end{array}$ \\
\hline
\end{tabular}

Dependent variable is the change in the natural log of the EFW index from 1980-2010. Robust standard errors in parentheses.

${ }^{*} p<0.05,{ }^{* *} p<0.01,{ }^{* * *} p<0.001$ 
in economic freedom. Returning to $\beta$-convergence, the coefficient in column (3) of 0.00642 implies that a country with a low level of EFW in 1980 such as Uganda will close the gap with the countries in the top quartile of the EFW at a rate of 0.642 percent per year, holding constant all the other factors in Column (3).

\section{Conclusion}

There is a small but growing literature on the determinants of economic freedom. In this paper I have contributed to this literature in two ways. First, I have empirically shown that $\beta$-convergence in economic freedom occurred from 1980 to 2010. Countries that started 1980 with low levels of economic freedom are converging on those at the top of the EFW ranking, albeit at a slow rate. Second, I have documented the initial conditions that have contributed to this institutional convergence. For example, countries where individuals 25 years of age and older had more years of secondary schooling in 1980 saw stronger convergence, other things being equal.

Most interestingly, I find no evidence of stronger convergence among countries with similar levels of democracy. Exitability, a variable created by Brown (2014) to capture how easy it is for citizens to "vote with their feet" is related to the change in economic freedom from 1980 to 2010 in a statistically significant manner across all specifications. This provides some indirect evidence to the importance of "exit" versus "voice" with respect to the question of institutional reform.

The results here suggest several other avenues for future research. First, Exitability is likely to be stronger within a country rather than across countries given the importance of passport controls and immigration restrictions. This suggest that areas within a country with greater Exitability are likely to have higher levels of economic freedom, ceteris paribus. This would be extremely easy to test with any of the sub- 
regional economic freedom indices, such as Stansel et al. (2014). This would fit in well with the literature on economic freedom and migration (Ashby, 2007; Cebula et al., 2015). Second, across countries there have been found many determinants of economic freedom that change considerably over a thirty-year period, such as joining fiscal or monetary unions (Hall et al., 2011), financial crises Rode and Coll (2012), populism (Rode and Revuelta, 2015), or human rights violations (Carden and Lawson, 2010). The effect of these variables on $\beta$-convergence of economic freedom could be analyzed in a panel data format. Finally, $\beta$-convergence of economic freedom across U.S. states could estimated to see if states were converging or diverging in terms of institutional quality since 1980 . 


\section{References}

Aixalá, J. and Fabro, G. (2009). Economic freedom, civil liberties, political rights and growth: a causality analysis. Spanish Economic Review, 11(3):165-178.

Alesina, A., Devleeschauwer, A., Easterly, W., Kurlat, S., and Wacziarg, R. (2003). Fractionalization. Journal of Economic Growth, 8(2):155-194.

Apergis, N., Dincer, O., and Payne, J. E. (2014). Economic freedom and income inequality revisited: Evidence from a panel error correction model. Contemporary Economic Policy, 32(1):67-75.

Ashby, N. J. (2007). Economic freedom and migration flows between U.S. states. Southern Economic Journal, 73(3):677-697.

Barro, R. J. and Lee, J. W. (2013). A new data set of educational attainment in the world, 1950-2010. Journal of Development Economics, 104:184-198.

Barro, R. J. and Sala-i-Martin, X. (1992). Convergence. Journal of Political Economy, $100(2): 223-251$.

Beaulier, S. A. and Subrick, J. R. (2006). The political foundations of development: the case of botswana. Constitutional Political Economy, 17(2):103-115.

Beck, T., Clarke, G., Groff, A., Keefer, P., and Walsh, P. (2001). New tools in comparative political economy: The database of political institutions. World Bank Economic Review, 15(1):165-176.

Boudreaux, C. and Holcombe, R. (2015). Institutional convergence. Working paper, Florida State University.

Brown, M. (2014). The geography of economic freedom. In Hall, J. C., editor, Economic Freedom and Economic Education: Ideas and Influence of James Gwartney, volume VI of The Annual Proceedings of the Wealth and Well-Being of Nations, chapter 7, pages 105-121. Beloit College Press, Beloit WI.

Carden, A. and Lawson, R. A. (2010). Human rights and economic liberalization. Business 8 Politics, 12(2):1-18.

Cebula, R. J., Foley, M., and Hall, J. C. (2015). Freedom and gross in-migration: an empirical study of the post-great recession experience. Journal of Economics and Finance, 16:1-19.

Clark, J., Lawson, R., Nowrasteh, A., Powell, B., and Murphy, R. (2014). Does immigration impact institutions? Public Choice, 163(3-4):321-335.

Crampton, E. (2002). You get what you vote for: Voter preferences and economic freedom. Journal of Private Enterprise, 18(Fall 2002):29-56. 
Dawson, J. W. (1998). Institutions, investment, and growth: New cross-country and panel data evidence. Economic Inquiry, 36(4):603-619.

Dawson, J. W. (2003). Causality in the freedom-growth relationship. European Journal of Political Economy, 19(3):479-495.

De Haan, J., Lundström, S., and Sturm, J.-E. (2006). Market-oriented institutions and policies and economic growth: A critical survey. Journal of Economic Surveys, 20(2):157-191.

De Haan, J. and Sturm, J.-E. (2003). Does more democracy lead to greater economic freedom? New evidence for developing countries. European Journal of Political Economy, 19(3):547-563.

Diamond, J. (1997). Guns, Germs, and Steel: The Fates of Human Societies. WW Norton \& Company, New York NY.

Du, J. (2010). Institutional quality and economic crises: Legal origin theory versus colonial strategy theory. Review of Economics and Statistics, 92(1):173-179.

Easterly, W., Ritzen, J., and Woolcock, M. (2006). Social cohesion, institutions, and growth. Economics \&f Politics, 18(2):103-120.

Efendic, A., Pugh, G., and Adnett, N. (2011). Institutions and economic performance: A meta-regression analysis. European Journal of Political Economy, 27(3):586-599.

Elert, N. and Halvarsson, D. (2012). Economic freedom and institutional convergence. Working Paper.

Glaeser, E. L., La Porta, R., Lopez-de Silanes, F., and Shleifer, A. (2004). Do institutions cause growth? Journal of Economic Growth, 9(3):271-303.

Gwartney, J. and Lawson, R. (2003). The concept and measurement of economic freedom. European Journal of Political Economy, 19(3):405-430.

Gwartney, J., Lawson, R., and Block, W. (1996). Economic Freedom of the World, 1975-1995. Fraser Institute, Vancouver.

Gwartney, J., Lawson, R., and Hall, J. (2015). Economic Freedom of the World: 2015 Annual Report. Fraser Institute, Vancouver.

Gwartney, J. D., Holcombe, R. G., and Lawson, R. A. (2006). Institutions and the impact of investment on growth. Kyklos, 59(2):255-273.

Gwartney, J. D., Lawson, R. A., and Holcombe, R. G. (1999). Economic freedom and the environment for economic growth. Journal of Institutional and Theoretical Economics, 155(4):643-663. 
Hall, J. C. and Lawson, R. A. (2014). Economic freedom of the world: An accounting of the literature. Contemporary Economic Policy, 32(1):1-19.

Hall, J. C., Lawson, R. A., and Wogsland, R. (2011). The European Union and economic freedom. Global Economy Journal, 11(3):1-14.

Heckelman, J. (2015). Economic freedom convergence clubs. In Cebula, R., Hall, J., Mixon, F., and Payne, J., editors, Economic Behavior, Entrepreneurship and Economic Freedom. Edward Elgar, Northampton MA.

Hirschman, A. O. (1978). Exit, voice, and the state. World Politics, 31(01):90-107.

Keefer, P. and Knack, S. (1997). Why don't poor countries catch up? A cross-national test of an institutional explanation. Economic Inquiry, 35(3):590-602.

Keefer, P. and Stasavage, D. (2003). The limits of delegation: Veto players, central bank independence, and the credibility of monetary policy. American Political Science Review, 97(3):407-423.

Knack, S. (1996). Institutions and the convergence hypothesis: The cross-national evidence. Public Choice, 87(3-4):207-228.

Knack, S. and Keefer, P. (1995). Institutions and economic performance: Cross-country tests using alternative institutional measures. Economics \& Politics, 7(3):207-227.

La Porta, R., Lopez-de Silanes, F., and Shleifer, A. (2008). The economic consequences of legal origins. Journal of Economic Literature, 46(2):285-332.

La Porta, R., Lopez-de Silanes, F., Shleifer, A., and Vishny, R. (1999). The quality of government. Journal of Law, Economics, and Organization, 15(1):222-279.

Lawson, R. A. and Clark, J. R. (2010). Examining the Hayek-Friedman hypothesis on economic and political freedom. Journal of Economic Behavior $\&$ Organization, $74(3): 230-239$.

Leeson, P. T. and Dean, A. M. (2009). The democratic domino theory: An empirical investigation. American Journal of Political Science, 53(3):533-551.

Leeson, P. T., Sobel, R. S., and Dean, A. M. (2012). Comparing the spread of capitalism and democracy. Economics Letters, 114(1):139-141.

Lundström, S. (2005). The effect of democracy on different categories of economic freedom. European Journal of Political Economy, 21(4):967-980.

Mankiw, N. G., Romer, D., and Weil, D. (1992). A contribution to the empirics of economic growth. Quarterly Journal of Economics, 107(2):407-437. 
Marshall, M. G., Gurr, T. R., and Jaggers, K. (2014). Polity IV Project: Political regime characteristics and transitions, 1800-2013. Dataset. Center for Systemic Peace, Vienna VA.

Nattinger, M. C. and Hall, J. C. (2012). Legal origins and state economic freedom. Journal of Economics and Economic Education Research, 13(1):25-32.

Pitlik, H. and Wirth, S. (2003). Do crises promote the extent of economic liberalization? An empirical test. European Journal of Political Economy, 19(3):565-581.

Powell, B. and Nair, M. (2012). On the governance of "not being governed". Review of Austrian Economics, 25(1):9-16.

Powell, B. and Ryan, M. (2006). Does development aid lead to economic freedom? Journal of Private Enterprise, 22(1):1-21.

Rode, M. and Coll, S. (2012). Economic freedom and growth: Which policies matter the most? Constitutional Political Economy, 23(2):95-133.

Rode, M. and Revuelta, J. (2015). The wild bunch! An empirical note on populism and economic institutions. Economics of Governance, 16(1):73-96.

Sala-i-Martin, X. X. (1996). The classical approach to convergence analysis. Economic Journal, 106(437):1019-1036.

Savoia, A. and Sen, K. (2012). Do we see convergence in institutions? A cross-country analysis. Working paper no. 33, Development Economics and Public Policy.

Scott, J. C. (2009). The art of not being governed: An anarchist history of upland Southeast Asia. Yale University Press, New Haven CT.

Sheehan, K. M. and Young, A. T. (2014). It's a small world after all: Internet access and institutional quality. Contemporary Economic Policy, 33(4):649-667.

Sobel, R. S. and Coyne, C. J. (2011). Cointegrating institutions: the time-series properties of country institutional measures. Journal of Law and Economics, 54(1):111-134.

Stansel, D., Torra, J., and McMahon, F. (2014). Economic Freedom of North America 2014. Fraser Institute, Vancouver.

Stringham, E. P. and Miles, C. J. (2012). Repelling states: Evidence from upland southeast asia. Review of Austrian Economics, 25(1):17-33.

Tiebout, C. M. (1956). A pure theory of local expenditures. Journal of Political Economy, pages 416-424.

Vega-Gordillo, M. and Alvarez-Arce, J. L. (2003). Economic growth and freedom: a causality study. Cato Journal, 23:199-216. 
Williamson, C. R. and Mathers, R. L. (2011). Economic freedom, culture, and growth. Public Choice, 148(3-4):313-335.

World Bank (2015). World Development Indicators. World Bank Publications.

Wu, W. and Davis, O. A. (1999). The two freedoms, economic growth and development: An empirical study. Public Choice, 100(1-2):39-64.

Young, A. T., Higgins, M. J., and Levy, D. (2008). Sigma convergence versus beta convergence: Evidence from us county-level data. Journal of Money, Credit and Banking, 40(5):1083-1093.

Young, A. T. and Sheehan, K. M. (2014). Foreign aid, institutional quality, and growth. European Journal of Political Economy, 36:195-208. 